\title{
Ants as shell collectors: notes on land snail shells found around ant nests
}

\author{
Barna PÁll-Gergely ${ }^{1} \&$ Péter Sólymos² \\ ${ }^{1}$ Department of General and Applied Ecology, University of Pécs, Ifjúság útja 6., H-7624 Pécs, Hungary, \\ e-mail: pallgergely2@gmail.com \\ ${ }^{2}$ Department of Mathematical and Statistical Sciences, University of Alberta, Edmonton, Alberta, T6G 2G1, Canada, \\ e-mail: solymos@ualberta.ca and Department of Ecology, Faculty of Veterinary Science, Szent István University, Rottenbiller \\ u. 50, H-1077 Budapest, Hungary
}

\begin{abstract}
PÁll-Gergely B. \& Sólymos P., 2009: Ants as shell collectors: notes on land snail shells found around ant nests. - Malacologica Bohemoslovaca, 8: 14-18. Online serial at $<$ http://mollusca.sav.sk $>$ 17-Mar-2009.
\end{abstract}

\begin{abstract}
We investigated the shell collecting activities of harvester ants (Messor spp.) in semi-arid grasslands and shrubs in Turkey. We found eleven species of snails in the area, two of them were not collected by ants. Eight - mainly small sized - snail species were found on ant nests in a habitat characterized by shrubs, three in rocky grassland and four in a grassland habitat. Some shells (e.g. Chondrus zebrula tantalus, Multidentula ovularis) might be taken into the nests, and we hypothesise that some of these snail species are consumed by ants (Monacha spp.). From a fauna inventory perspective, shell collecting activities of harvester ant may help malacologists to find snail species which are normally hidden for a specialist (e.g. Oxychilus hydatinus, Cecilioides spp.) due to their special habits.
\end{abstract}

Key words: Formicidae, Messor, Monacha, harvester ants, snails, ecology

\section{Introduction}

Although there is only one myrmecophilous snail species, which has been reported as actually living in ant nests (WITTE et al. 2002), shells of several species are known being gathered by foraging harvester ants. The shell collecting behaviour of ants has been studied by VERDCOURT (1957, 2002), Urbański (1965), Mienis (1974) and SeIDL (1987) so far. Messor harvester ants are thought to be typically non-carnivorous species which feed on seeds, fruits and carcasses. Hence, it is puzzling why especially these ants collect shells. They may collect snails because the latter often resemble seeds in size and shape, or they feed on live snails or the carcasses of dead ones URBAŃSKI (1965).

We investigated ant nests in semiarid grasslands and shrubs in Turkey in order to better understand the ant-snail relationship in natural habitats. We were interested in gathering information on topics such as whether the samples were biased by the size and/or shape of the snail species. This was done by comparing the snail fauna in or near ant nests with local snail diversity. Furthermore, we speculate on clues to what extent harvester ants consume some snail species.

\section{Material and Methods}

Field sampling was carried out on the area of the Dumlupınar University, Turkey (Fig. 1), between the cami and Hüsnü Özyeğin Öğrenci Yurdu (student dormitory), 10 15 October, 2007 on an altitude of about $1050 \mathrm{~m}$ above sea level (geographic coordinates: $39.4811^{\circ} \mathrm{N}, 29.8889^{\circ} \mathrm{E}$ (using Google Earth). The habitat of about five hectares, which consisted of a relatively uniform secondary steppe with rocks and shrubs (mainly Juniperus, Quercus, Crataegus) in some places.

Ant nests were evenly distributed over the area, with an average distance of 10-14 $\mathrm{m}$ from each other. Entrance mounds of the largest nests could be $1 \mathrm{~m}$ in diameter. In general, ant nests generally consisted of a circa $0.3 \mathrm{~m}$ high central mound surrounded by a small amount of litter. This litter contained remnants of seeds and fruits (mostly Poaceae, Asteraceae, Medicago, Rumex, and Triburus).

Litter composition around nests may vary greatly, because different colonies collect different seeds (Traniello \& Beshers 1991). The demarcation of a single nest-mound was sometimes difficult due to the dispersed nest entrances (Heller 1971). Therefore it was also difficult to find the center of the nests. However it was usually marked by well visible foraging routes around the nest entrance.

We used 10 paired quadrats $(0.25 \times 0.25 \mathrm{~m}$ each $)$ to collect litter from the soil surface. Each quadrate pair consisted of a near (max. $0.3 \mathrm{~m}$ from the nest entrances) and a far $(3 \mathrm{~m}$ from the nest entrance) samples. In this way we sampled 10 ant nests. We then compared the samples to see which snail species were collected by the ants and whether ants collect shells selectively from the available overall local snail population.

Besides the quadrate pairs, we investigated shells found around nests in three habitat types: shrubs, rocky steppe and steppe. We collected $3 \times 1$ litter samples from each 


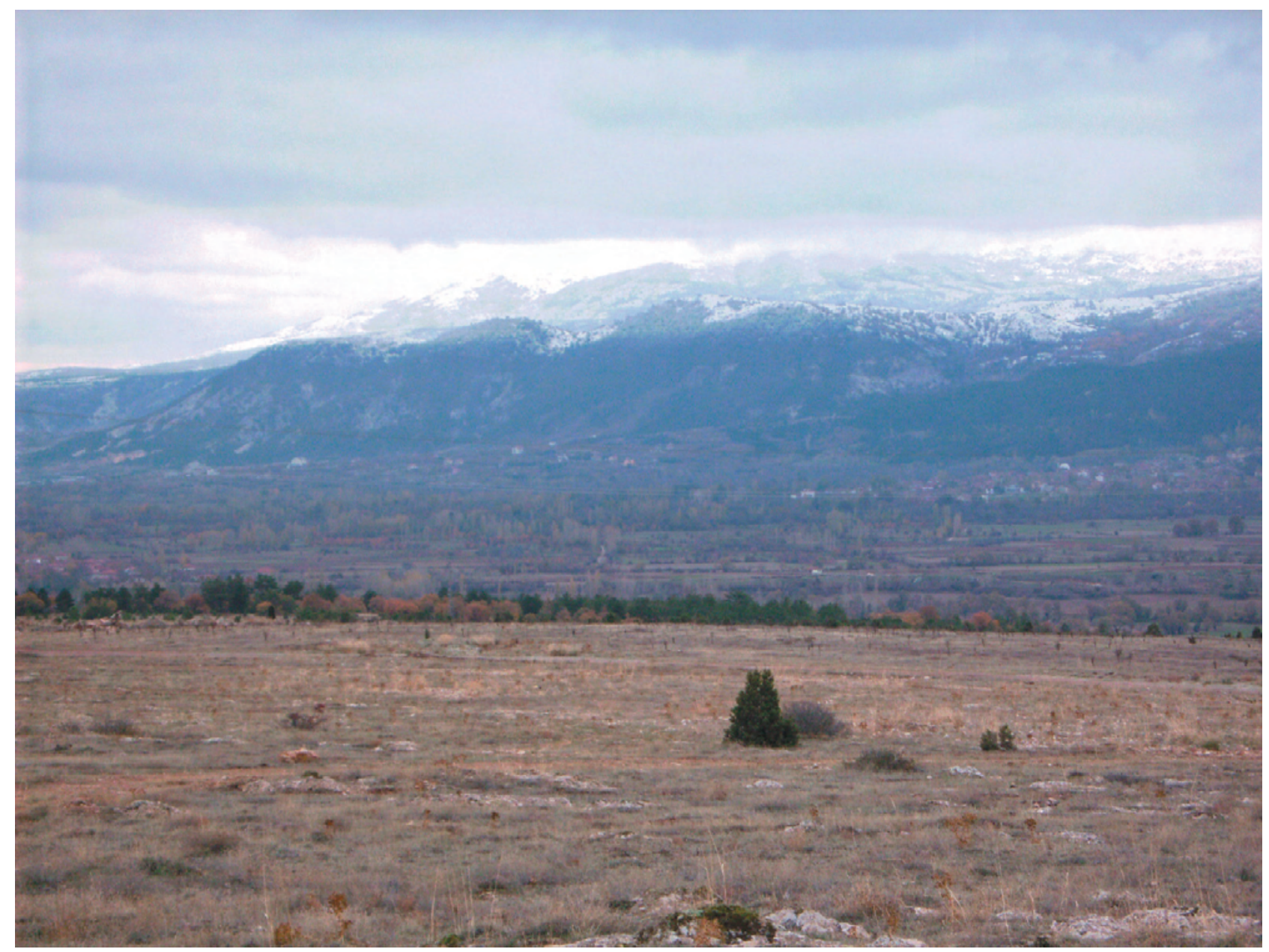

Fig. 1. Sampling site near Dumlupınar University, Kütahya, Turkey.

habitat type. In order to have more data on ant nests, we collected further $47 \times 1$ litter samples from the vicinity of ant nests in the steppe habitat (altogether 50 samples with the previous three). We complemented quadrate samples by visual search in the field to get a more complete list of the snail fauna.

All the shells were sorted and identified in the laboratory. We could not find living specimen of Monacha (Paratheba) bithynica Hausdorf, 2000, possibly because of the late autumn season, when the species is not active. The identification of the species was dubious, because it is hard to distinguish between this and its congeners (M. margarita, Hausdorf, 2000, M. crenophila (L. Pfeiffer, 1857), M. ovularis (Bourguignat, 1855)) based solely on shell characters. However, HAUSDORF (2000) found this species in nearby areas. One living specimen of Monacha (Monacha) solidior (Mousson, 1863) was found, thus its identification is supported by anatomical evidence. Identity of juveniles of Helix lucorum Linnaeus, 1758 was based on the two adult shells found in the territory. We only counted the number of shell apices to avoid multiple counting of the same shell.

For the nomenclature of the snail species we used the work of SснÜтт (2001). Collected Messor specimens are deposited in the Hymenoptera collection of the Hungarian Natural History Museum, and the snail shells are in the private collection of the senior author.

\section{Results}

We collected ant workers and soldiers which were stored in alcohol. We found two ant species Messor oertzeni Forel, 1910 and Messor caducus (Victor, 1839) in the area, but their relative abundances was not determined. From several nests 20 specimens of $M$. oertzeni and 41 specimens of M. caducus were collected. Empty shells were observed on anthills of both species.

Samples from the three habitat types revealed nine snail species (Table 1). The number of species in the grassland and rocky grassland habitats was low (four and three species, respectively) compared to the shrubs (eight species). Zebrina kindermanni (L. Pfeiffer, 1850) was found only

Table 1. Total counts of the collected species in the three habitat types. Counts are from three litter samples pooled.

\begin{tabular}{lccc}
\hline Species & shrub & $\begin{array}{c}\text { rocky } \\
\text { grassland }\end{array}$ & grassland \\
\hline Ch. zebrula tantalus & 85 & 157 & 87 \\
M. bithynica & 44 & 44 & 83 \\
X. obvia & 19 & 22 & 89 \\
M. ovularis & 52 & - & - \\
H. subcalcarata neuberti & 19 & - & - \\
M. solidior & 6 & - & - \\
H. lucorum & 3 & - & - \\
O. hydatinus & 1 & - & - \\
Z. kindermanni & - & - & 15 \\
\hline
\end{tabular}




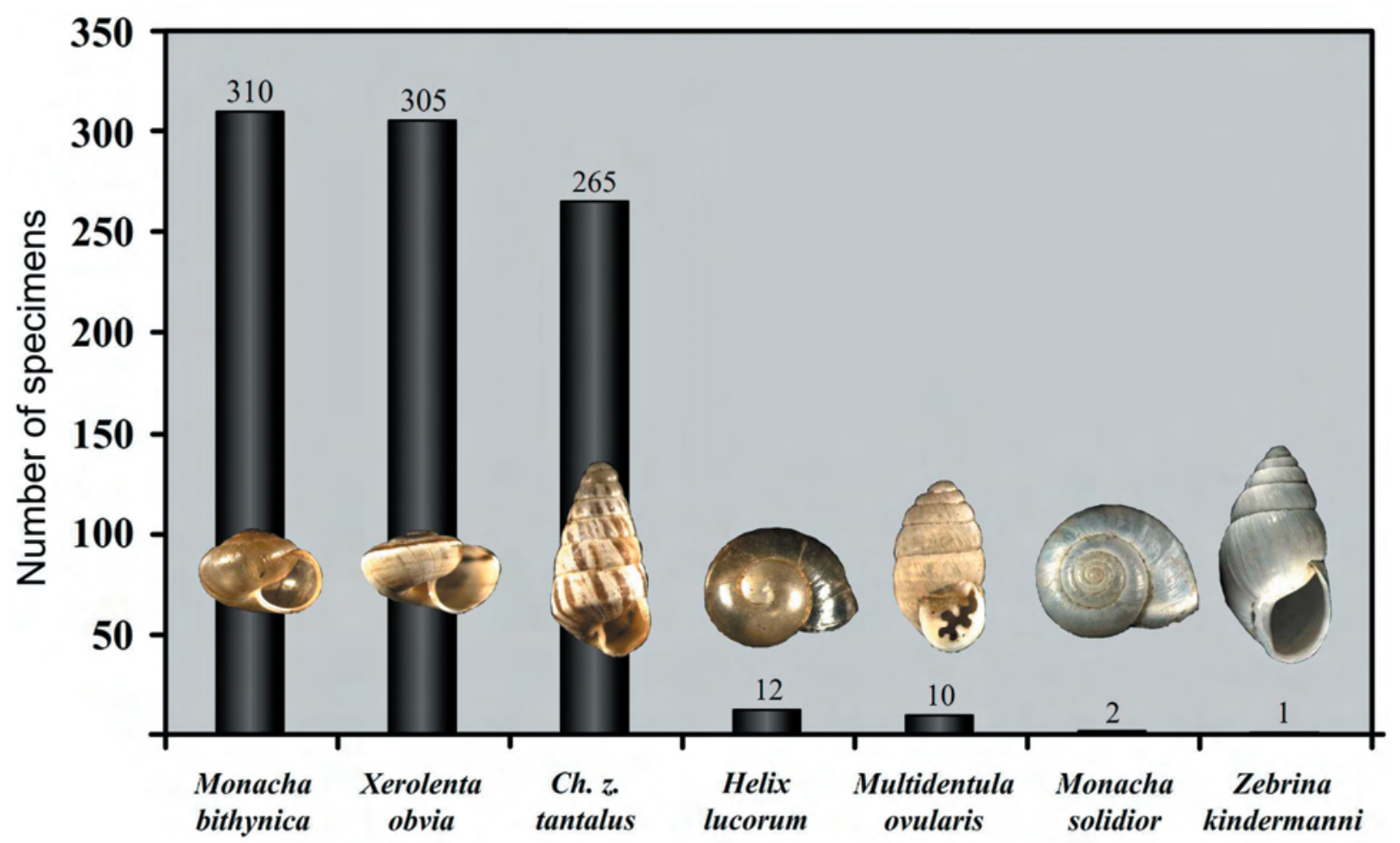

Fig. 2. Total abundances of the species collected from the grassland habitat $(50 \times 1$ litter samples are pooled). Shell pictures are not proportional. The pictures of X. obvia, Ch. zebrula tantalus, and H. lucorum show juvenile shells, because jveniles of these three species were more frequent than adults on the anthills.

in the grassland, Chondrus zebrula tantalus (L. Pfeiffer, 1868) was most common in the rocky steppe. Xerolenta obvia, M. bithynica, and Ch. zebrula tantalus were equally common in the steppe habitat. Besides the grassland species, five species were found only in the shrubs (Table 1). The 50 soil samples collected in the steppe habitat revealed seven species. The most common species were the same as in the above comparison: X. obvia, M. bithynica, and $C h$. zebrula tantalus. In addition four species occurred infrequently (Fig. 2).

A total of 50 Monacha bithynica, eight Xerolenta obvia (Menke, 1828), two Helix lucorum and one Helicopsis subcalcarata neuberti Hausdorf, 1990 shells were found in the ten near samples of the paired quadrates, while we found only one $M$. bithynica in the ten samples three meters apart from the nests.

During a complimentary search, we found the five shrub species in the steppe areas as well except for Oxychilus (Mediterranea) hydatinus (Rossmässler, 1838). These were however eroded shells found around small shrubs. In addition we also found some specimens of Zebrina detrita (O.F. Müller, 1774), H. subcalcarata neuberti, and Helix (Pelasga) escherichi O. Boettger, 1898 during the visual search, which were not encountered in the litter samples. The species Zebrina detrita was found only with additional search besides bushes. The species is probably too big to be transported by ants. One specimen of Zebrina kindermanni was found in a litter sample from the grassland. It was rarely found during visual search.

The thin shelled species Monacha bithynica was the most common species in all habitat types. Sixty percent (173 out of 310) of the shells were perforated in a similar way, on the penultimate whorl (Fig. 3). The species M. solidior was found only in the shrubs. The shells were perforated as in the other Monacha species. It is likely that the perforations are made by ants to reach the soft body of the snail.

Chondrus zebrula tantalus was common in ant nest garbage. Most of the specimens were juveniles with few whorls. We found only 73 fully grown undamaged adults out of 265 individuals. Apertures of the juvenile shells were filled by mud, thus presumably these were collected by ants in a not so fresh stage, and probably the shells were found in the soil during digging the ducts. The shells of the rare species Multidentula ovularis (Olivier, 1801) were clean and undamaged.

One specimen of Oxychilus hydatinus was found during visual search from nest garbage. The species lives underground and is rarely found alive (KERNEY et al. 1983). In the shrubs the species was more common and was also found

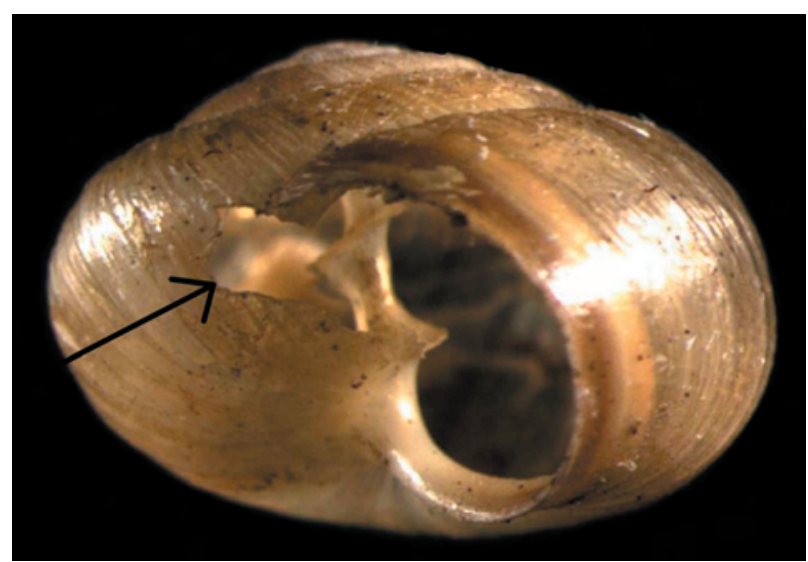

Fig. 3. Shell of Monacha bithynica perforated probably by ants (see hole at the tip of the arrow) 
in nest garbage. Most probably the ants found these shells in the underground ducts.

The species Helicopsis subcalcarata neuberti was rarely found only during the visual search. It is more abundant in the shrubs. Shell apertures were dusty, thus ants might find them during nest construction. Xerolenta obvia was common; almost all the specimens possessed only few whorls, and were less than $0.7 \mathrm{~cm}$ in diameter.

Helix escherichi was found only during the visual search, especially in the shrub habitat. During this search, two adults were found of the species H. lucorum. Freshly hatched juvenile (embryonic) shells were abundant in nests.

\section{Discussion}

As a result of different shell collecting activities of ants, all of the shells can be found around the nests, together with unconsumed vegetable parts. Some shells have been collected distant from the nests, whereas others might be found during building the nest under the soil. The determination of the origin of the collected shells is not obvious, so we can just conjecture it knowing the lifestyle of the snail species.

The shell collecting activity of ants is not unique for the investigated area. VerdCourT $(1957,2002)$ has reported Curvella myrmecophila Verdcourt, 2002 in nests of a Myrmicaria species in Tanzania, URBAŃSKI (1965) found shells (mainly Bulgarica thessalonica (Rossmässler, 1839)) in the nest of Messor rufitarsis (Fabricius, 1804) in Southern Bulgaria. In the same paper, he mentions Formica pratensis Retzius, 1783 (as Formica rufa pratensis) as a shell collecting ant species. SEIDL (1987) found shells around the nests of the ant Lasius niger (Linnaeus, 1758). MiENIS (1974) indicates that in Israel, harvesting ants collect shells.

Besides these reports, Sándor Csősz (Hungarian Nat. Hist. Mus., Budapest, Hungary) has found small shells around nests of Pheidole ants in south-western Turkey (S. Csösz, pers. comm.). András Varga (Mátra Museum, Gyöngyös, Hungary) has found Cecilioides acicula (O.F. Müller, 1774) shells being removed from nests by the ant species Tetramorium caespitum (Linnaeus, 1758) near Pásztó (foot of Mátra Mts., northern Hungary; catalogue number: MMGY 5878). Péter Sólymos found Cecilioides petitiana (Benoit, 1862) shells in entrances of the super-colony of Lasius neglectus Van Loon, Boomsma \& Andrásfalvy, 1990 ant species in Budatétény (Budapest, Hungary) in an abandoned orchard.

There are few direct observations on how and why ants carry snails and shells into their nests. In the field we discerned only one Messor ant worker as it was carrying a Ch. zebrula tantalus shell. It is likely that ants take all movable pieces of shells into the nests, and later those are deposited on the surface of the nest mound which is build of garbage. For most of the species, we assume that ants confuse shells with seeds. It is unlikely that ants would consume Chondrus zebrula tantalus and Multidentula ovularis, because the apertures of the shells are very narrow. Shells might be taken as seeds. But for some species, especially Monacha and juvenile Helix individuals are presu- mably on their menu, but the latter does not make up high proportion of their diet due to its rarity.

It is likely that ants encounter Oxychilus hydatinus shells during nest construction. The exterior of the shells were clean and the bodies of the snails were desiccated in the interior. Thus, ants did not fed on this snail species.

According to the comparison of near vs. far quadrates we can suggest that ants sample snails selectively. Some species (Zebrina detrita, Helix escherichi) were not recorded near the entrances of the ant nests. This can be explained by the large size of these species.

More snail species (shells) were represented near the nest entrances in shrubs, where snail diversity is higher than in grasslands. Common grassland species (Z. detrita, Z. kindermanni, Ch. zebrula tantalus, $M$. bithynica, X. obvia, $H$. escherichi) found also in the shrubs, has wider drought tolerances than the shrub preferring species (M. ovularis, $O$. hydatinus, $M$. solidior, $H$. subcalcarata neuberti, $H$. lucorum). The two Monacha species showed slightly distinct habitat preferences: $M$. solidior was more frequent in shrubs, $M$. bithynica in the more open grassland.

The previous results match with our observations. (1) The fauna of the area consists of more species that were found around the ant nests. (2) Large bodied species were found less frequently in the nests. (3) Most shells resembled seeds. But we found no clue about the significance of snails in the food of ants.

We conclude that shells found on the area of ant nests represent only part of the local snail fauna, viz. the smaller species or juveniles from larger species. Further, it seems plausible to state that some snail species with thin shells may be consumed regularly by ants. Thus, when dealing with shells found around the ant nests (which is appealing because of the high concentration of shell compared to average density in the surroundings), we should take into account the shell selectivity of ants.

From a fauna inventory perspective, ants may help malacologists to find species that live underground.

\section{Acknowledgements}

Thanks are due to Sándor Csősz (Hungarian Natural History Museum) for helpful comments and identifying the ant species, András Tartally (Szent István University) for his advices, Barnhard Hausdorf (University of Hamburg) for help in snail identification, and Gábor Majoros (Szent István University) for identifying seeds. Henk K. Mienis (Hebrew University of Jerusalem) provided useful literature; András Varga (Mátra Museum, Gyöngyös) provided his collection data. PS was supported by a postdoctoral fellowship of the NSERC and the Alberta Biodiversity Monitoring Institute. This study was financially supported by the Student Union of Faculty of Sciences, University of Pécs (Pécs, Hungary).

\section{References}

Heller G., 1971: Beitrag zur Kenntnis der im Gebiet von Schwabenheim/Selz (Rheinhessen) vorkommenden Amaisenarten. Unpublished Master's thesis. Johannes Gutenberg-Universitat Mainz, Mainz, 45 pp.

Kerney M.P., Cameron R.A.D. \& Jungbluth J.H., 1983: Die 
Landschnecken Nord- und Mitteleuropas. - Verlag Paul Parey, Hamburg und Berlin, 384 pp.

MienIs H.K., 1974: Mieren als verzamelaars van slakkenhuisjes [Ants as collectors of snail shells]. - Correspondentieblad van de Nederlandse Malacologische Vereniging, 158: 257-258.

Sснӥтт H., 2001: Die Türkischen Landschnecken 1758-2000. 3.

Vollständig revidierte und erweiterte Auflage. - Acta Biologica Benrodis, Supplementband 4, 549 pp.

SeIDL F., 1987: Schwarze Gartenameisen (Lasius niger) als Schneckensammler. - Mitteilungen der Zoologischen Gesellschaft Braunau, 5 (1-4): 49-52.

Traniello J.F.A. \& Beshers S.N., 1991: Polymorphism and size-pairing in the harvester ant Pogonomyrmex badius. A test of the ecological release hypothesis. - Insectes Sociaux 38:
$121-127$.

URBAŃSKi J., 1965: Ernteameisen als Sammler von Schneckengehäusen. - Mitteilungen der Deutschen Malakozoologischen Gesellschaft, 6: 72.

VerdCourt B., 1957: Snails in ants' nests. - Entomologists' Monthly Magazine 93: 41.

Verdcourt B., 2002: Two new species of Curvella Chaper (Gastropoda, Pulmonata, Subulinidae) from the East Usambara Mts., Tanzania. - Basteria 66: 107-122.

Witte V., Janssen R., Eppenstein A. \& Maschwitz U., 2002: Allopeas myrmekophilos (Gastropoda, Pulmonata), the first myrmecophilous mollusc living in colonies of the ponerine army ant Leptogenys distinguenda (Formicidae, Ponerinae). - Insectes Sociaux 49: 301-305. 